\title{
Mechanistic Evaluation of the Effect of Calcium Carbide Waste on Properties of Asphalt Mixes
}

\author{
N. Isa ${ }^{1 *}$, A. Olowosulu ${ }^{1}$, M. Joel ${ }^{2}$ \\ ${ }^{1}$ Department of Civil Engineering, Ahmadu Bello University, Zaria, Nigeria. \\ ${ }^{2}$ Department of Civil Engineering, University of Agriculture, Makurdi, Nigeria.
}

\begin{abstract}
Calcium Carbide Waste (CCW) was used as an alternative to traditional Portland cement mineral filler in hot mix asphalt concrete to rid its disposal problem. Its effect on mechanical properties of hot mix asphalt was assessed using the Marshall method of mix design. Using the optimum bitumen content determined from Marshall Test, Portland cement used as mineral filler was partially replaced with 0,10, 20, 30, 40 and 50\% CCW by dry weight. Results of tests indicated an increase in stability, voids in mineral aggregates, Marshall Stiffness and reduction in flow, unit weight, voids filled with binder when the percentage of CCW increases. Based on results of tests, partial replacement of Portland cement with $40 \% \mathrm{CCW}$ could be used in asphalt production. This will ensure economy in asphalt production and promote disposal of $\mathrm{CCW}$ which constitute environmental hazards.
\end{abstract}

KEYWORDS: Calcium Carbide Waste, Asphalt, Portland cement, Mineral Filler, Mechanical Properties.

[Received July 26 2017; Revised November 19 2017; Accepted December 20 2017]

\section{INTRODUCTION}

Asphalt is a mixture of bitumen, coarse aggregate, fine aggregate and mineral filler in different proportions, depending on the type of asphalt mixture (Garber and Hoel, 2009). One of the major problems associated with the use of asphalt in road works is the high cost of the constituent material which in turn necessitates the development of innovative paving materials. While developing these new paving materials, current attention has been directed at the use of industrial waste to address environmental and economic concerns (Aisien et al., 2006). The vast amount of waste materials produced daily is one of the major worldwide problems in waste management (Ratnasamy et al., 2009). Developing countries like Nigeria produce considerable amounts of wastes from ceramic, steel industry and coal-fired power plants every year. These huge amounts of waste create a significant problem with respect to handling and storage. The use of these materials can actually add value to what was once a costly disposal problem. Using industrial wastes in asphalt concrete pavement can not only decrease environmental problems but also improve some properties of the pavement (Ratnasamy et al., 2009).

Researchers have been investigating the use of waste materials in the construction industry, to enable better management of these wastes and improve the properties of construction materials. Burak and Ali, (2004) investigated the use of asphalt roofing shingles in hot mix asphalt, and observed that waste shingles as an additive can improve the Marshall stability and rutting resistance of the asphalt mixtures. Aisien et al., (2006) investigated the application of ground scrap tyre rubbers in asphalt concrete pavement, and observed that the rubberized asphalt concrete mix has much better mechanical properties than the conventional mix. Sinan and Emine, (2004) investigated the use of waste high density polyethylene (HDPE) as bitumen modifier in asphalt concrete

*Corresponding author’s e-mail address: nuhamz@gmail.com mix, their findings shows that waste HDPE modified bituminous binders provide better resistance against permanent deformation due to their high stability and high Marshall Quotient.

Fillers as one of the components in asphalt mixture, consist of finely divided mineral matter such as rock dust, slag dust, hydrated lime, hydraulic cement, fly ash, loess or other suitable mineral matter (Ritter and Paquette, 1951). Conventional fillers as listed above are often used as antistripping agents as a result of their respective hydrophobic nature. This plays a major role in determining the properties and the behavior of the mixture, especially the binding and aggregate interlocking effects (Ritter and Paquette, 1951). The filler has the ability to increase the resistance of particle to move within the mix matrix and/or work as an active material when it interacts with the bitumen to change the properties of the mastic. (Ratnasamy et al., 2011)

Calcium Carbide waste is a waste material generated from oxy-acetylene gas used in welding works (Chukwudebelu et al., 2013). Calcium Carbide Waste is abundant in our environment and researches have been conducted to determine its use as a civil engineering construction material. Nattapong et al., (2010) investigated the effects of calcium carbide residue-fly ash Binder on mechanical properties of concrete and observed that the hardened concrete produced from calcium carbide residue fly ash mixtures had mechanical properties similar to those from normal Portland cement concrete. Joel and Edeh (2014) investigated the stabilization of Ikpayongo lateritic soil with cement and calcium carbide waste and observed that calcium carbide waste can partially be used in the stabilization of Ikpayongo laterite. Du et al., (2011) investigated the strength and California bearing ratio properties of natural soils treated with calcium carbide residue and reported that calcium carbide residue can be adopted as an alternative binder to 
treat over-wetted soils being used as highway embankment filling materials.

Different researchers have investigated the use of CCW in concrete works (Nattapong et al., 2010, Heni et al., 2014, Hongfang et $a l .$, 2015) and soil stabilization (Du et $a l ., 2011$, Songsuda et al., 2013, Joel et al., 2014), little has been done in the use of the waste in Asphalt production. The high cost of conventional materials used in asphalt production coupled with the hazardous effect of $\mathrm{CCW}$ on the environment necessitated this study which is aimed at investigating the effect of partial replacement of mineral filler with calcium carbide waste in hot mix asphalt concrete. Outcome of the research will be beneficial to engineers in the road construction industry.

\section{MATERIALS AND METHOD}

\section{A. Aggregates}

Coarse and fine aggregates used in the preparation of asphalt concrete mixtures were sourced from PW quarry site along Angwa-Maijero road, 0331897E, 1161485N Kaduna with specific gravity values presented in Table 3 . In this study, two sizes of coarse aggregate were used.

The selected gradation of aggregate incorporated in all asphalt concrete specimens confirms to the mid - point of the standard aggregate gradation specified in the Federal Ministry of Works Highway Design Manual (2013). Table 1 presents the selected mix gradation.

Table 1: Aggregate Gradation.

\begin{tabular}{cccc}
\hline $\begin{array}{c}\text { Particle } \\
\text { Size }(\mathbf{m m})\end{array}$ & $\begin{array}{c}\text { Particle } \\
\text { Size (in) }\end{array}$ & \% Passing & $\begin{array}{c}\text { Mean } \\
\text { Grading }\end{array}$ \\
\hline $\mathbf{1 9 . 1}$ & $3 / 4$ & 100 & 100 \\
$\mathbf{1 2 . 7}$ & $1 / 2$ & $80-100$ & 90 \\
$\mathbf{9 . 5 2}$ & $3 / 8$ & $70-90$ & 80 \\
$\mathbf{4 . 7 6}$ & No. 4 & $50-70$ & 60 \\
$\mathbf{2 . 3 8}$ & No. 8 & $35-50$ & 42 \\
$\mathbf{0 . 5 9}$ & No. 30 & $18-29$ & 23 \\
$\mathbf{0 . 2 9 7}$ & No. 50 & $13-23$ & 18 \\
$\mathbf{0 . 1 1 9}$ & No. 100 & $8-16$ & 12 \\
$\mathbf{0 . 0 7 4}$ & No. 200 & $4-10$ & 7 \\
\hline (Source: FMWHM, 2013) & &
\end{tabular}

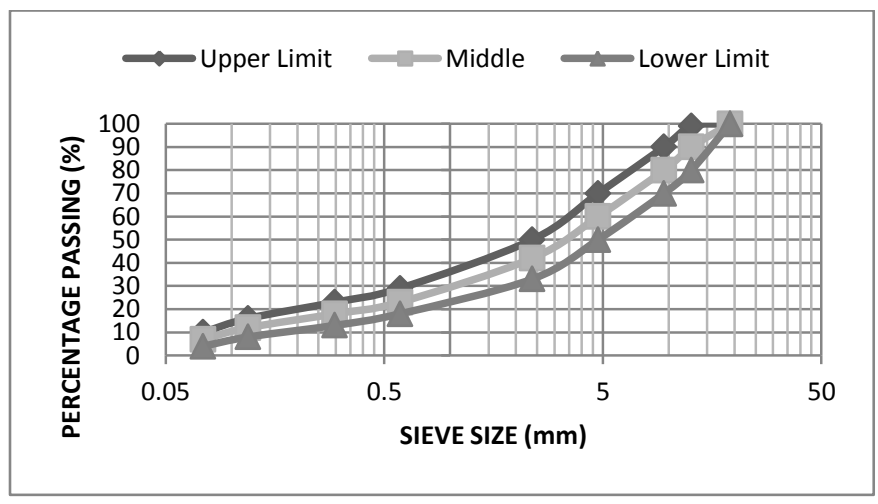

Figure 1: Aggregate gradation used in this study.

\section{B. Mineral Filler and Bitumen}

The fillers used in this investigation include Portland cement which was obtained from cement retailer and calcium carbide waste from automobile welders shop in Panteka Kaduna. Calcium carbide was used as a percentage of $0 \%$, $10 \%, 20 \%, 30 \%, 40 \%$ and $50 \%$ Portland cement. 60/70 penetration grade bitumen used in this study was obtained from NNPC Kaduna refinery. The bitumen was subjected to penetration, ductility and specific gravity test in accordance with ASTM D5, D113, D70 respectively to determine its physical properties.

\section{Methods}

Laboratory investigations were conducted to determine optimum bitumen content for the control mix using different bitumen content, according to the Marshall method of mix design (ASTM D1559). Although Marshall method is essentially empirical, it is useful in comparing mixtures under specific conditions. Therefore it was used in this research work. Using an optimum bitumen content of $5.8 \%$ obtained from the conventional mix, asphalt concrete specimens were prepared with Portland cement partially replaced with 0,10 , $20,30,40,50 \%$, calcium carbide waste and the results were compared with the Nigerian General Specification for Roads and Bridges (NGSRB, 1997) standards presented in Table 2.

Table 2: Properties of compacted asphaltic concrete.

\begin{tabular}{lll}
\hline Property & Base-Course & Wearing Course \\
\hline $\begin{array}{l}\text { Optimum Bitumen } \\
\text { content }\end{array}$ & $4.5 \%-6.5 \%$ & $5.0 \%-8 \%$ \\
Stability not less than & $3.5 \mathrm{kN}$ & $3.5 \mathrm{kN}$ \\
Flow & $2 \mathrm{~mm}-6 \mathrm{~mm}$ & $2 \mathrm{~mm}-4 \mathrm{~mm}$ \\
Voids in total mixture & $3 \%-8 \%$ & $3 \%-5 \%$ \\
$\begin{array}{l}\text { Voids filled with } \\
\text { bitumen (VFB) }\end{array}$ & $65 \%-72 \%$ & $75 \%-82 \%$ \\
\hline (Source: NGSRB, 1997) & & \\
\hline
\end{tabular}

\section{RESULTS AND DISCUSSION}

The specific gravities of coarse and fine aggregates obtained are as presented in Table 3 . The specific gravity of fine aggregate is higher than those for the coarse aggregates. For a particular aggregate type or source, fine aggregate specific gravities can be slightly higher than coarse aggregate specific gravities because as the aggregate particles get smaller, the fraction of pores exposed to the aggregate surface increases (Pavement Interactive, 2011). The specific gravity values are within the range reported by other researchers (Mahesh et al., 2009; Hassan et al., 2011; Talal et al., 2013; Ratnasamy and Eltaher, 2011).

Table 3: Specific gravity of coarse and fine aggregates.

\begin{tabular}{lc}
\hline Aggregate Type & Average Specific Gravity \\
\hline Coarse $12.7 \mathrm{~mm}$ & 2.631 \\
Coarse $9.52 \mathrm{~mm}$ & 2.638 \\
Fine Aggregate & 2.667 \\
\hline
\end{tabular}

All the percentage passing sieve 30,50 and 200 of both Portland cement and calcium carbide waste conformed with the range specified by ASTM D242; Portland cement and 
calcium carbide waste are non-plastic (NP), with specific gravity of Portland cement being 3.15 and that of calcium carbide waste 2.42 . The mineral filler properties reported in Table 4 are within the ranges reported by other researchers (Talal et al., 2013; Hassan et al., 2006) and ASTM D242 which makes the result satisfactory.

Table 4: Average physical properties of mineral fillers.

\begin{tabular}{lccc}
\hline Sieve (mm) & \multicolumn{2}{c}{ Passing } & $\begin{array}{c}\text { ASTM } \\
\text { D242 }\end{array}$ \\
& Portland Cement & $\begin{array}{c}\text { Waste } \\
\text { Warbide }\end{array}$ & $\begin{array}{c}\text { D2400 } \\
\text { No. 30 (0.59) }\end{array}$ \\
No. 50 (0.297) & 100 & 100 & $95-100$ \\
No. 200 (0.074) & 100 & 100 & $70-100$ \\
Plasticity Index & 94 & 92 & $<4$ \\
Specific Gravity & NP & NP & ---- \\
\hline
\end{tabular}

The result of the physical properties of bitumen used presented in Table 5 shows that the bitumen is a $60 / 70$ pen grade bitumen with a penetration of 70 , a ductility of $100+$ and a specific gravity of 1.027. All these values conform to the range specified in the Nigerian General Specifications for Road and Bridges (1997).

Table 5: Physical properties of bitumen.

\begin{tabular}{lccc}
\multicolumn{1}{c}{ Test } & Unit & ASTM & $\begin{array}{c}\text { Result } \\
(\mathbf{6 0} / 70)\end{array}$ \\
$\begin{array}{l}\text { Penetration, } \\
100 \mathrm{~g}, 25^{\circ} \mathrm{C}\end{array}$ & $0.1 \mathrm{~mm}$ & $\mathrm{D} 5$ & 70 \\
$\begin{array}{l}\text { Ductility, } \\
5 \mathrm{~cm} / \text { min., } 25^{\circ} \mathrm{C}\end{array}$ & $\mathrm{cm}$ & $\mathrm{D} 113$ & $>100$ \\
$\begin{array}{l}\text { Specific Gravity } \\
\text { at } 25^{\circ} \mathrm{C}\end{array}$ & ---- & $\mathrm{D} 70$ & 1.027 \\
\hline
\end{tabular}

The results of all Marshall Stability tests using the designed asphalt ratio of 5.8\% are summarized in Table 6 for mixtures with different $\mathrm{CCW}$ content. All results shown for each specimen are the average value of three tests.

\section{A. Effect of CCW on Marshall Stability}

The relationship between Marshall Stability value and CCW content in Figure 2 clearly shows that the stability value increases with CCW content up to $40 \%$, then decreased. This is due to the aggregates which tend to be finer as CCW content increases; therefore there exists a reduction in the stability value at $50 \% \mathrm{CCW}$. The reduction in stability at $50 \%$ CCW content can also be attributed to the high voids in mineral aggregates within the mix which requires a high compactive effort to achieve high stability value. Samples with $40 \%$ calcium carbide waste after 30 minutes immersion in water bath have the highest Marshall stability value.

Although there was inconsistency in these results with respect to $\mathrm{CCW}$ content, the difference between the Marshall stability values were not notably high from $0-50 \%$ replacement. This might be attributed to particles from $\mathrm{CCW}$ filling the void between the coarse and fine aggregate component of asphalt. A positive stability results were obtained with the replacement of Portland cement with CCW because they were above the Nigerian General Specification of roads and Bridges (1997) standard of not less than $3.5 \mathrm{kN}$.

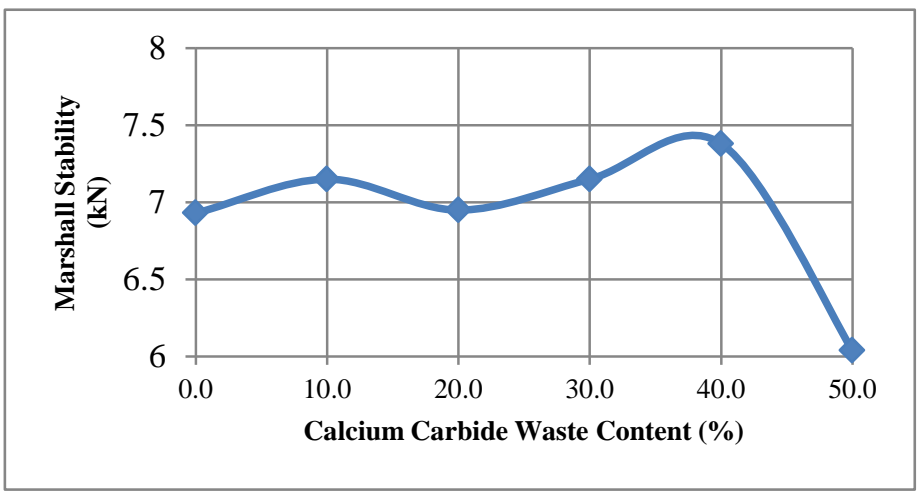

Figure 2: Variation of Marshall Stability with CCW content.

Table 6: Marshall Stability test results for mixtures with different carbide waste content at $5.8 \%$ bitumen content.

\begin{tabular}{|c|c|c|c|c|c|c|c|}
\hline $\begin{array}{l}\text { Marshall } \\
\text { Properties }\end{array}$ & $\begin{array}{c}\text { Stability } \\
(\mathbf{k N})\end{array}$ & $\begin{array}{l}\text { Flow } \\
(\mathbf{m m})\end{array}$ & $\begin{array}{c}\text { Bulk } \\
\text { Density } \\
\left(\mathrm{gm} / \mathrm{cm}^{3}\right)\end{array}$ & $\begin{array}{c}\text { Air } \\
\text { Voids } \\
\%\end{array}$ & $\begin{array}{l}\text { Voids in } \\
\text { Mineral } \\
\text { Aggregate } \\
\text { VMA \% }\end{array}$ & $\begin{array}{c}\text { Voids Filled } \\
\text { with } \\
\text { Binder } \\
\%\end{array}$ & $\begin{array}{c}\text { Mar-shall } \\
\text { Stiff- } \\
\text { ness } \\
\text { kN/mm }\end{array}$ \\
\hline $\begin{array}{l}\text { NGSRB } \\
1997 \\
\text { Require- } \\
\text { ments }\end{array}$ & $\begin{array}{l}\text { Not less } \\
\text { than } 3.5\end{array}$ & $2-4$ & - & $3-5 \%$ & $\begin{array}{l}\text { Not less } \\
\text { than } 15 \%\end{array}$ & $75-82$ & - \\
\hline $\begin{array}{l}\text { Calcium } \\
\text { carbide }\end{array}$ & & & & & & & \\
\hline $\begin{array}{l}\text { waste, } \% \\
\text { (by wt. of } \\
\text { filler } \\
\text { material) }\end{array}$ & \multicolumn{7}{|c|}{ Asphalt content, $\%$ (by wt. of total mix) $=5.8 \%$} \\
\hline 0.0 & 6.93 & 5.64 & 2.379 & 3.65 & 21.87 & 83.31 & 1.23 \\
\hline 10.0 & 7.15 & 4.90 & 2.375 & 3.65 & 21.76 & 83.23 & 1.46 \\
\hline 20.0 & 6.95 & 4.66 & 2.369 & 3.74 & 22.18 & 83.14 & 1.49 \\
\hline 30.0 & 7.15 & 5.39 & 2.344 & 4.59 & 23.01 & 80.05 & 1.33 \\
\hline 40.0 & 7.38 & 4.17 & 2.337 & 4.57 & 23.26 & 80.35 & 1.77 \\
\hline 50.0 & 6.04 & 4.66 & 2.312 & 5.44 & 23.92 & 77.26 & 1.30 \\
\hline
\end{tabular}




\section{B. Effect of CCW on Marshall Flow}

Variation of flow with CCW content is shown in Figure 3. Decline in Marshall flow was observed at $10 \%, 20 \%, 40 \%$ $\mathrm{CCW}$ replacement. The reduction in flow values with the introduction of $\mathrm{CCW}$ can be attributed to $\mathrm{CCW}$ particles being finer than OPC particles and stiffens the mixture more than OPC. The increment in flow at $30 \%$ and $50 \% \mathrm{CCW}$ content can be attributed to the sliding action of particles within the mix.

This behavior was equally observed by (Hassan et al., 2011) when glass powder was used to replace ordinary Portland cement and limestone powder. The Nigerian general specification for Road and Bridges (1997) flow value of $4 \mathrm{~mm}$ was satisfied when cement was replaced with $40 \% \mathrm{CCW}$.

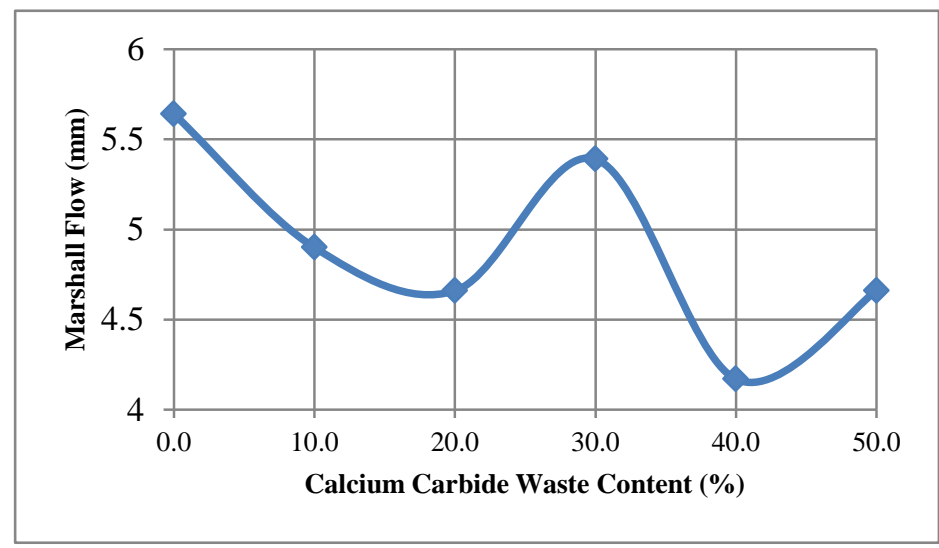

Figure 3: Variation of marshall flow with CCW content.

\section{Effect of CCW on Bulk Density}

The effect of CCW content on bulk density of compacted mixes is shown in Figure 4. Mixes showed a trend of decrease in bulk density as CCW content increases. This is because while $\mathrm{CCW}$ content increases in the mix, it fills the voids within the aggregates and at higher content of $\mathrm{CCW}$, the stiffness of the mix increased which in turn needs a greater compaction effort then consequently less dense mixtures obtained. The decrease in bulk density can also be attributed to the low specific gravity of CCW. This trend is similar to that observed by Hassan et al., (2011) when glass powder was used to replace limestone powder and ordinary Portland cement.

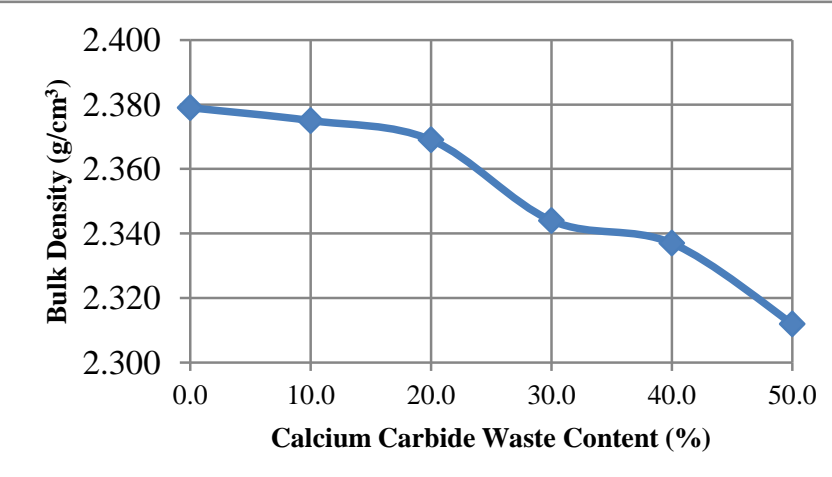

Figure 4: Variation of bulk density with $\mathrm{CCW}$ content.

\section{Effect of CCW on Voids in Total Mix}

The effect of CCW content on voids in total mixtures of compacted mixes is shown in Figure 5. The air void content for mixes with $0 \%-40 \% \mathrm{CCW}$ were all within the range of $3 \%-5 \%$ specified by the Nigerian General Specification for Roads and Bridges (1997). Values of 5.44\% obtained when cement was replaced with $50 \% \mathrm{CCW}$ were above the value recommended by the Nigerian code. High air voids are associated with high permeability, which will affect the performance of the surfacing made with such mix.

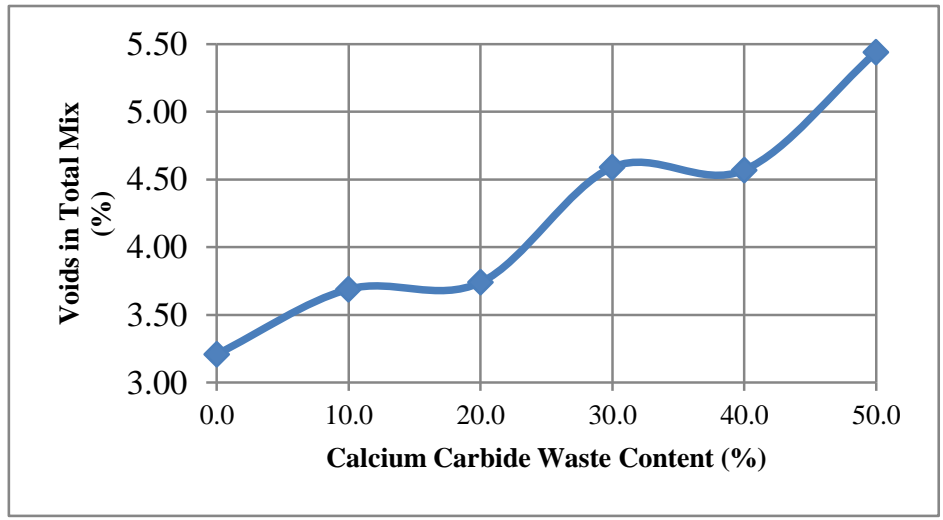

Figure 5: Variation of Voids in Total Mix with CCW content

\section{E. Effect of $C C W$ on Voids in Mineral Aggregate}

The effect of CCW on voids in mineral aggregates is shown in Figure 6. It is a common trend that, as filler content in the mixes increase, the void in the mineral aggregates decrease up to a minimum value then increases at higher content as could be seen from Figure 6 . The voids in mineral aggregates increases with $\mathrm{CCW}$ content, this could be attributed to the fact that $\mathrm{CCW}$ is coarser than Portland cement. This effect further explains the reduction in the bulk density of the mix. The voids in mineral aggregates values all lie within the permissible limits specified in the Federal Ministry of Works Highway Design manual (2013).

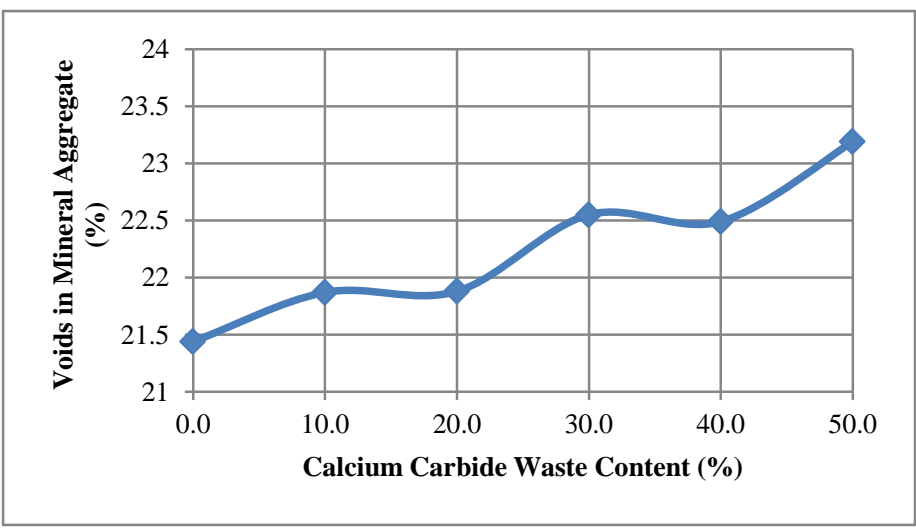

Figure 6: Variation of Voids in Mineral Aggregate with CCW content. 


\section{F. Effect of CCW on Voids Filled with Binder}

Effect of CCW on voids filled with binder is shown in Figure 7. Voids filled with binder value increase with $\mathrm{CCW}$ content, and all are above $75 \%$, where the Marshall criteria for voids filled with binder (VFB) is $75 \%$ - 82\%. This criterion is important because it affects the durability of mixes and is related to the optimum bitumen content in the mix. If the percentage of voids filled with binder is lower than the limit indicated, there will be less bitumen film around the aggregate particles. On the other hand at $\mathrm{CCW}$ contents of $0 \%, 20 \%$, and $30 \%$, the limit is exceeded and more voids are filled with bitumen than required for durability, this may result in bleeding.

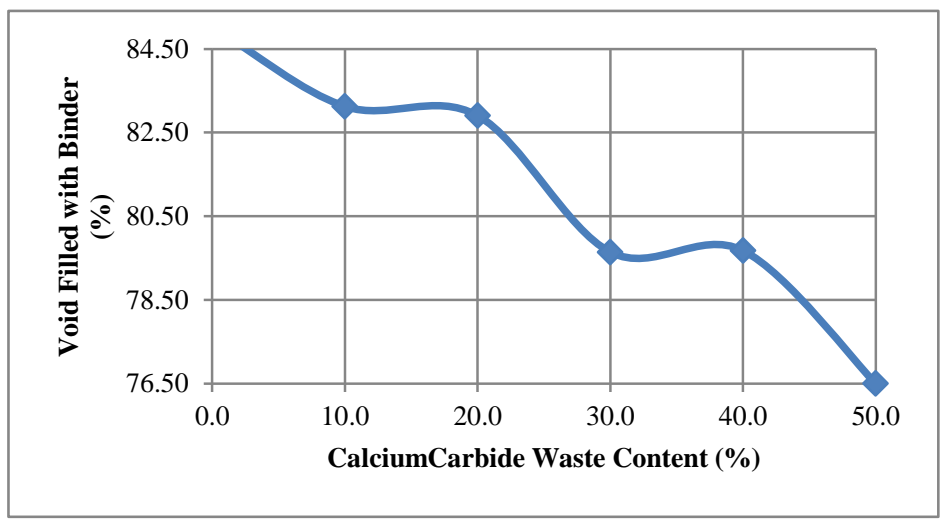

Figure 7: Variation of Void Filled with Binder with CCW content.

\section{G. Effect of CCW on Marshall Stiffness}

Figure 8 shows the relationship between Marshall Stiffness and CCW content. The Marshall Stiffness (MS), that is, stability divided by its flow, is an empirical stiffness value and is used by some engineers, especially in Europe, to evaluate the strength of asphalt mixture (Talal et al., 2013). A higher value of MS indicates a stiffer mixture and hence, it indicates that the mixture is likely more resistant to permanent deformation (Talal et al., 2013). Marshall Stiffness of mixture as shown in Figure 8 were found to be satisfactory when compared to the value obtained with the control mix of $0 \% \mathrm{CCW}$. The plot indicates that Marshall Stiffness increased with CCW content, this is also reflected in Figure 3.

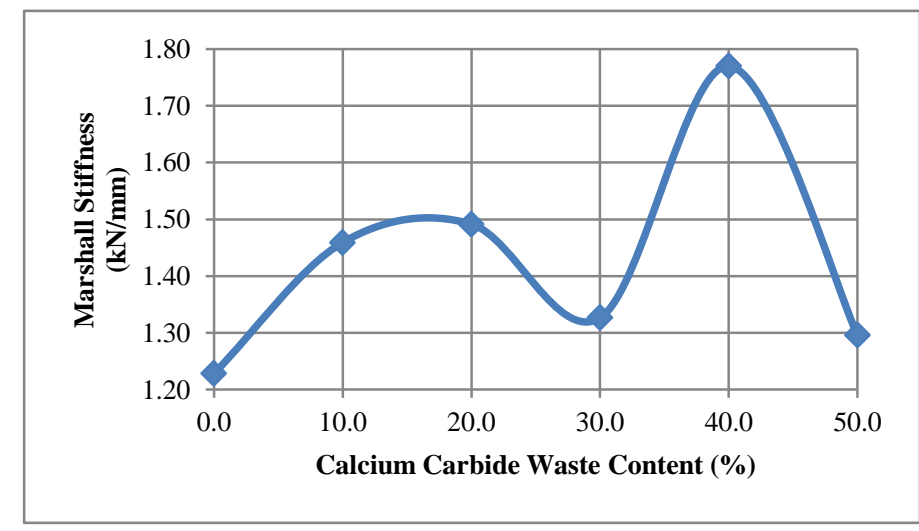

Figure 8: Variation of marshall stiffness with CCW content.

\section{CONCLUSION}

In this study, Calcium Carbide Waste (CCW) was used as an alternative to traditional Portland cement mineral filler in hot mix asphalt concrete to rid its disposal problem. The results are summarized below:

i. Results of the tests conducted on $\mathrm{CCW}$ to determine its suitability for use as mineral filler showed a specific gravity value of 2.42 , plasticity index value of 0 (nonplastic) with $92 \%$ passing sieve No.200. These values confirmed its suitability for use as mineral filler in accordance with ASTM D242.

ii. Optimum bitumen content value of $5.8 \%$ was achieved after conducting Marshall Stability tests on specimens containing Portland cement as conventional mineral filler. Stability values increased from $6.93 \mathrm{kN}$ at $0 \%$ $\mathrm{CCW}$ to a maximum value of $7.38 \mathrm{kN}$ at $40 \% \mathrm{CCW}$ content. The Flow value of $4.17 \mathrm{~mm}$ at $40 \% \mathrm{CCW}$ satisfies the Nigerian General Specification for Roads and Bridges (1997) standards.

iii. Flow values reduced from $5.64 \mathrm{~mm}$ at $0 \% \mathrm{CCW}$ to a minimum value of $4.17 \mathrm{~mm}$ when cement was replaced with $40 \% \mathrm{CCW}$ which subsequently resulted in a stiffer mix.

iv. The Unit Weight of asphalt generally reduced from $2.379 \mathrm{~g} / \mathrm{cm}^{3}$ at $0 \% \mathrm{CCW}$ to a minimum value of $2.312 \mathrm{~g} / \mathrm{cm}^{3}$ at $50 \% \mathrm{CCW}$ content. Air voids increased from $3.21 \%$ at $0 \% \mathrm{CCW}$ to a maximum value of $5.44 \%$ at $50 \% \mathrm{CCW}$ content. Voids in Mineral Aggregate values also increased from $21.44 \%$ at $0 \% \mathrm{CCW}$ to a maximum value of $23.19 \%$ when cement was partially replaced with $50 \% \mathrm{CCW}$.

v. Voids filled with Binder decreased from $85.02 \%$ at $0 \%$ $\mathrm{CCW}$ to a minimum value of $76.50 \%$ at $50 \% \mathrm{CCW}$ content. Marshall Stiffness values increased with CCW content and peaked at $40 \% \mathrm{CCW}$ replacement $(1.77$ $\mathrm{kN} / \mathrm{mm})$.

\section{REFERENCES}

Aisien, F.A,; F. K. Hymore and R. O. Ebewele. (2006). Application of Ground Scrap Tyre Rubbers in Asphalt Concrete Pavements. Indian Journal of Engineering and Material Sciences, 13: 333-338.

ASTM (2004). International Standard Testing for Road and Paving Materials; Vehicle-Pavement Systems.

Burak, S. and Ali, T. (2004). Use of Asphalt Roofing Shingle Waste in HMA. Construction and Building Materials. 19: 337-346.

Chukwudebelu, J. A.; C. C. Igwe, O. E. Taiwo and O. B. Tojola. (2013). Recovery of pure slaked lime from carbide sludge: Case study of Lagos State, Nigeria. African Journal of Environmental Science and Technology, 7(6): 490-495.

Du, Y. J.; Y. Y. Zhang and S. Y. Liu. (2011). Investigation of Strength and California Ratio Properties of Natural Soils Treated by Calcium Carbide Residue. GeoFrontiers: Advances in Geotechnical Engineering, 1237-1244.

Federal Ministry of Works (2013). Highway manual Part 2: Maintenance works", Abuja, Nigeria.

Garber, J. and Hoel, A. (2009). Traffic and Highway Engineering (4th ed.). Toronto, Canada: Cengage Learning,. 
Hassan, H. J.; F. Mays and Y. J. Israa. (2011). The Effect of using Glass Powder Filler on Hot Asphalt Concrete Mixture Properties. Engineering and Technology Journal, 29(1): 44-56.

Heni, P. and Ngudiyono (2014). Effect of Curing Time and Repeated Drying-Wetting on Properties of Clay Stabilized with Calcium Carbide Residue, Trass and Fibre Plastic Waste. International Journal of Civil and Environmental Engineering, 14(6): 1-4.

Hong, S.; L. Zishanshan, B. Jing, A. M. Shazim, D. Biqin, F. Yuan, X. Weiting and X. Feng. (2015). Properties of Chemically Combusted calcium Carbide Residue and its Influence on Cement Properties. Materials, 8(1): 638-651.

Joel, M. and Edeh, J. (2014). Stabilization of Ikpayongo Laterite with Cement and Calcium Carbide Waste. Global Journal of Pure and Applied Sciences, 20(1): 49-55.

Nattapong, M.; J. Chai and L. Thanapol. (2010). Effect of Calcium Carbide Residue-Fly Ash Binder on

Mechanical properties of Concrete. Journal of Materials in Civil Engineering, 22(11): 1164-1170

Nigerian General Specifications Roads and Bridgeworks (1997). Federal ministry of works, Lagos, Nigeria.

Ratnasamy, M. and Eltaher, E. A. (2011). The Effect of Type and Particle Size of Industrial Wastes Filler on Indirect Tensile Stiffness and Fatigue Performance of Stone Mastic Asphalt Mixtures. Australian Journal of Basic and Applied Sciences, 5(11): 297-308.

Ratnasamy, M.; Eltaher, E. A., Hussain, H. and Robiah, Y. (2009). An Initial Investigation of the use of Local Industrial Wastes and By-products as Mineral Fillers in Stone Mastic Asphalt Pavements. ARPN Journal of Engineering and Applied Sciences, 4(3): 54-63.

Sinan, H. and Eminie, A. (2004). Use of Waste High Density Polyethylene as Bituminous Modifier in Asphalt Concrete Mix. Materials Letters, 58: 267-271.

Songsunda, V., R. Runglawan and H. Suksun. (2013). Strength and Microstructure Development in Bangkok Clay Stabilized with Calcium Carbide Residue and Biomass Ash. ScienceAsia, 39(1): 186-193.

Ritter, Jr, J. L. and Paquette, R. J. (1951). Highway Engineering (1st ed.). Gainesville, Florida: The Ronald Press Company, New York.

Talal, H. F.; S. J. Salah, E. A. Kahlil and S. A. Ahmed. (2013). Influence of using white cement kiln dust as a mineral filler on hot asphalt concrete mixture properties. International Journal of Civil Engineering and Technology, 4(1): 87-96. 